\title{
Developing a lean measurement system to enhance process improvement
}

\author{
P. Lewis` and G. Cooke
}

Engineering Management Department, Engineering and Computing Faculty, Coventry University, Engineering and Computing Building, 3 Gulson Road, Coventry CV1 2JH, UK

Received: 4 July 2013 / Accepted: 4 November 2013

\begin{abstract}
A key ingredient to underpin process improvement is a robust, reliable, repeatable measurement system. Process improvement activity needs to be supported by accurate and precise data because effective decision making, within process improvement activity, demands the use of "hard" data. One of the oldest and most established process improvement methods is Deming's Plan-Do-Check-Act (PDCA) cycle which is reliant on the check phase, a measurement activity where data is being gathered and evaluated. Recent expansions of the PDCA such as the Six-Sigma Define-Measure-Analyse-Improve-Control (DMAIC) methodology place significant importance upon measurement. The DMAIC cycle incorporates the regimented requirement for the inclusion of measurement system analysis (MSA) into the breakthrough strategy. The call for MSA within the DMAIC cycle is to provide the improvement activity with a robust measurement system that will ensure a pertinent level of data during any validation process. The Lean methodology is heavily centred on the removal of the seven Mudas (wastes) from a manufacturing process: defects, overproduction, transportation, waiting, inventory, motion and processing. The application of lean, particularly within the manufacturing industry, has led to a perception that measurement is a waste within a manufacturing process because measurement processes identify defective products. The metrologists' pursuit for measurement excellence could be construed as a hindrance by the "cost down" demands being perpetrated from the same organisation's lean policy. So what possible benefits does enforcing the regimes of the lean and quality philosophies upon the measurement process have and how does this ultimately enhance the process improvement activity? The key fundamental to embed with any process improvement is the removal of waste. The process improvement techniques embedded within lean and quality concepts are extremely powerful practices in the drive to eradicate waste but there are numerous contextual problems with the application of the process improvement activity and its associated measurement system. The application demands of the organisation may be dependent on a number of financial and resource constraints which may introduce reasons not to apply stringent measurement methodology and practice. The failure of various process improvement activities due to poorly managed measurement activity has arguably never been comprehensively analysed. Process improvement activity theory fully embellishes the need for applied robust measurement systems, so how can process improvement and measurement be systematically aligned to gain benefits? The aim of this paper is to consider whether lean philosophies can be integrated and applied within measurement systems. The discussion seeks to identify if seven Muda exist within measurement systems and whether in doing so this will lead to benefits for process improvement activities.
\end{abstract}

Keywords: Lean measurement; Muda; DMAIC; PDCA; Deming

\section{Introduction}

This research is concerned with investigating manufacturing based measurement systems and confirming that measurement is a key fundamental within any process improvement activity; any form of measurement is a process and as such can be subjected to improvement activity.

Within the manufacturing industry there has always been a necessity for products to physically conform to

\footnotetext{
^ Correspondence: aa5041@coventry.ac.uk
}

specifications. This responsibility for insurance of conformity normally relies on the inspection, quality and metrology function to present an acceptance stamp. The development of manufacturing within the realms of process improvement has led to the need for data to enable actions. Process improvement elements can relate to the part to part variation and the use of statistics to remove the common causes and thus move towards process capability in line with the six sigma methodology. Management functions also need robust data to support decision making processes in line with strategic level decision making. 
The key fundamental principle within total quality management is the need to continuously improve, whether it is product, processes or organisational performance [1-4]. If any organisation does not deploy some term of improvement whilst it competitors are advancing then instead of standing still an organisation will be in effect declining in performance. There are different configurations and approaches to achieving levels of improvement.

Two of the most recognised process improvement concepts, PDCA and DMAIC, display subtle differences in the expectations and demands of their theoretical measurement activity. When a measurement system is applied into a process improvement activity a multitude of complications and complexities arise such as data manipulation and interpretation. There are immense differences in knowledge, ability and experience within organisations towards measurement systems and the associated MSA. The contextuality within the process improvement activity coupled with increasing product expectations can result in poorly specified requirements for the measurement system.

The lean methodology is another key improvement process and centres round the concept of understanding the end customer's perception of value. From this identification of value, the lean methodology perpetuates the removal of an activity which is felt to be non-value adding. The lean methodology divides these non-value activities into a series of seven areas and terms them "the seven Mudas of manufacturing".

Some of the lean theorists filter a message through that measurement is an evil. Bicheno [5] states "you cannot fatten the calf by weighing it" but without measuring the calf's medical status how do you prevent the entire herd from being destroyed due to a disease or infection. Perhaps the underlying lean message should be to ensure that the right entity is being measured?

The concept of the Mudas is a cornerstone of Lean which has its origins rooted within manufacturing processes and is constantly applied within the design of contempory manufacturing facilities. The Muda concept is currently being adopted and adapted into different sectors such as the UK's National Health Service (NHS) in the Institute of Innovation and Improvement ${ }^{1}$. Within the NHS lean concepts, such as the "seven Mudas of manufacturing" have been modified to remove the "car factory brutality", to create a patient friendly adaptation in order to support and enable advances in the hospital ward and operating theatre. This apparent transferability of the Muda concept presents the question "if the seven Mudas can be adopted by the NHS - how can they be applied to measurement systems"?

Therefore this paper will explore the possibility of assigning the Muda concept to measurement systems and processes, with the intention of articulating a process improvement concept for measurement systems, which has the objective of removing non value added activity and thus improving the efficiency of a measurement based function.

\footnotetext{
1 Institute.nhs.uk (2006) accessed February 2013.
}

\section{Literature review}

\subsection{The lean methodology}

There have been many successful concepts within Japanese industry $[6,7]$, which have been transferred to the Western arena. One of these concepts is lean. Lean is the term adopted by Womack and Jones [8] which encompasses the manner in which the Toyota Motor Company manages its production operations. The lean philosophy continues to progress and adapt along with its supporting literature [9-12]. Although the lean philosophy emerged within the manufacturing industry and specifically the Japanese automotive industry, it is currently being adopted by social and service type industries such as the NHS [13].

Womack et al. [14] define lean as:

"Lean thinking is lean because it provides a way to do more and more with less and less - less human effort, less equipment, less time, and less space - while coming closer and closer to providing customers with exactly what they want".

The key fundamental of the lean arena is to provide the customer with value. Lean Research $[8,14,15]$ explores this concept and relates a parallel message to many of the "quality" philosophies in that value is what the customer says it is. The identification of the customers perception of "value" allows a process to be analysed and the allocation of which elements are "value adding" and which are "nonvalue adding".

- Value Added Activity (VA) - An activity which increases the value (customer's perception of value) of a product.

- Non Value Added Activity (NVA) - An activity which is undertaken by the organisation but does NOT provide any increase in value of a product.

The lean philosophy enables the separation of a process into value added activity and non-value added activity; there are many arguments as to the ratio of value add to non-value add within any process but typical figures are between $1: 10$ and 1:100. Using the optimistic ratio of 1:10 the analogy can be put in place that $10 \%$ of the measurement process is value added activity and $90 \%$ of the process is non-value added activity. The purchasing of a highly technical piece of equipment will obviously speed up the measurement process but will erode into the value adding $10 \%$ figure and reduce this element but the $90 \%$ of non-value adding activity is still present. Whereas investigating and removing the non-value adding activity can potentially have a huge impact on the measurement system. A reduction of $10 \%$ within non-value adding activity is as influential as a $90 \%$ reduction within the value adding activity.

Researchers $[5,16]$ state that lean is not simply a set of tools which can be cherry picked to solve a plethora of problems but the contextual concept of value needs to 
be measured and defined. Bicheno [5] conveys the message that lean is not purely a process of Muda/waste removal $[9,11,17]$ but should be viewed proactively as a Muda/waste prevention exercise.

One of the main cornerstones of all improvement activity is the removal of events which impede profit generation. Ohno [18] labeled these events under the concept of non-value added costs. Ohno [18] further subdivides and labels these activities as production wastes and subsequently they have become globally known as the "seven Mudas of Manufacturing".

1. Muda from overproduction: To produce sooner, faster or in greater quantities than the absolute customer demand, manufacturing too much, too early or "just in case".

2. Muda of inventory: Any raw material, work in progress (WIP) or finished goods which are not having value added to them.

3. Muda of motion: Motion is the movement of "man", waste motion occurs when individuals move more than is necessary for the process to be completed.

4. Muda of waiting: People or parts that wait for a work cycle to be completed, the locations where waiting occurs are referred to as bottlenecks.

5. Muda of transportation: Unnecessary movement of parts between processes which are due to events such as: complex material flow paths, wasted floor space and unnecessary material handling.

6. Muda of over-processing: Processing beyond the standard required by the customer. Improving processing efficiency to ultimately use less resource to achieve the same customer satisfaction.

7. Muda of product defects: A defect is a component which the customer would deem unacceptable to pass their quality standards. Defects reduce or discourage customer satisfaction, defects have to be rectified, rectification costs money with regard to time effort and materials.

Liker [19] extended the original concepts of the manufacturing Muda and promotes the addition of an eighth Muda into the framework.

8. Muda of unused employee creativity: Losing time, ideas, skills, improvements and learning opportunities by not engaging or listening to your employees.

The concept and message of the Mudas is supported repeatedly within literature $[5,20,21]$ and researchers are considering the relationship with the manufacturing industry. Other authors [22-24] are taking the Muda concept and transferring it into service industry. One thing that is evident within the literature on Muda is that there is no definitive statement of "measurement is a waste" despite the perception. However, as with any other process, there is the opportunity to identify wastes within the measurement processes.

\subsection{Quality improvement and process improvement}

The differing approaches used to achieve continuous improvement require the implementation of some form of measurement. There has to be a series of measurements taken to establish a current level of performance. The measurement technique used to review performance must be replicated to the original measures to ensure a consistency of data. The exclusion of certain data sets or readjustment of boundaries to create an illusion of progression will only mask root causes and create an atmosphere of delusion and deception within an organisation $[25,26]$.

Deming stated his seven deadly sins, which are acknowledged as his contextual practices, will hinder the achievement and attainment of quality in an organisation. The response to the seven sins are Deming's fourteen principles of transformation. There is an argument that Deming disputes the measurement arena with principle three - "cease dependence on inspection" [27]. Whereas Deming is actually in dispute with the concept of final third party verification and is demanding process ownership and management, arguably pushing for upstream measurement processes. This is supported by further evaluation of Deming's principles specifically principle five "improve constantly and forever the system of production and service" [27] which infers a need for continuous improvement and a measured improvement over time. Thus Deming is clearly illustrating the demand for effective measurement systems which are precise and accurate to enable gains to be identified.

The four quadrants of the PDCA cycle all play vital roles within process improvement but the "Check" element is providing an important source of information for process improvement. The need to "measure" not only the conformity of the product but also the status of the process is vital. Without some format of robust measurement system to appraise not only the product but that of the "quality achievement" level, then how can an organisation understand where it is at and if it is genuinely getting better or is purely stagnating and fooling itself into thinking it is being competitive $[25,28]$. The underlying concept of the cycle is to measure, check, inspect or review the activity that has been undertaken and learn from what has happened, whether it be positive or negative, and put the new knowledge gained into making the process better and thus perpetuating the continuous improvement cycle.

Shingo [29] discusses a synonymous link between measurement and inspection processes and expands inspection into three distinct methods:

- Judgement inspection - inspections that discovers defects.

- Informative inspection - inspections that reduce defects.

- Source inspection - inspections that eliminate defects.

Shingo [29] showed dismay that organisations frequently held the judgement inspection mentality and condemned considerable resources to yes - no decisions, with no additional benefit. The authors' perception is that this activity is still currently prevalent within industry. If an organisation is undertaking concepts such as MSA and gauge Repeatability and Reproducibility (R\&R) the organisation can build a fantastically robust measurement system, which is capturing extremely capable data, $[30,31]$ but if 
the data gained from the measurement system is solely used to make a judgement inspection then the organisation needs to consider the complexity of the measurement system to avoid an over processing Muda [18].

Shingo [29] defines informative inspection as a method which takes the measurement data and feeds back into the relevant process and create some form of corrective measure which enables "improvement" and the reduction of defects. Shingo repeats the language of Deming and demands the use of "action" which will bring to life informative inspection reiterating the PDCA cycle.

Shingo amplifies the measurement arena into source inspection looking to remove defects before they happen. Shingo later expands source inspection to mirror the cause and effect principle, to measure controlling factors at source so the cause of the errors are eliminated rather than having to deal with measuring the effects which materialise as defects. Shingo is surely highlighting the need to be Simple, Measurable, Achievable, Realistic, Timed (SMART) when an organisation is deciding what to measure with the inference that the measurement system should be pushed upstream to control critical to quality parameters on the actual process thus preventing substandard product being produced and consequently the need to undertake extensive measurement on product.

\section{Discussion}

\subsection{The mudas of measurement}

The benefit of identifying and classifying the wastes within the measurement system presents the opportunity for an organisation to focus on their measurement process and even start to associate cost, both monetary and time, with the possibility of starting to align similarly to the BS61431:1992 Process Cost Model allowing the thought of measurement costs. The benefit of aligning issues within the measurement system into waste category allows the development and mind-set to be created that practices within industry, which have just been accepted common practice, are actually problems.

Personnel within the metrology field will have a stronger tolerance to the issues being identified as wastes and accept them but disciplines that are outside of the metrology or quality family, but dependent on its support, may kindly accept the 'necessary evil'. Management disciplines and accountants who view any non-direct cost as a must for removal will potentially view measurement as an area to minimise. The aforementioned staff could be making these decisions without fully comprehending the benefit gained from the measurement system, such as data which is vital in the perpetuation of process improvement.

In a similar vein to the NHS Institute of Innovation and Improvement, the inspiration is to synthesise the Muda concept and apply it to the measurement process. The following is an initial investigation into identifying issues within a measurement environment that are non-value adding activity and introduce extra unwanted costs and resource issues into a measurement system (Tab. 1).

\subsection{Lean measurement systems within process improvement}

Shingo is typically identified with the lean concepts such as Poke Yoke (mistake proofing) and SMED (Single Minute Exchange of Dies) which is seen in an opposite light to Deming's philosophy of the need to reduce variation as the key fundamental of process improvement. Shingo is linked to the yes/no mentality associated with the Poke Yoke philosophy. The Shingo perception of measurement within a lean environment is perceived with the use of dedicated gauging such as in its simplest form Go/No Go plug gauging. This typifies the basic judgement inspection which obviously has its place in the relevant measurement environment. This methodology will only ever provide limited data in the support of process improvement activity.

Organisations need to critically review, during the purchasing process, why they are investing in a high value piece of metrology equipment (either outright or high daily rental cost) and if it is being utilised within a measurement system on the basis of only receiving a judgement inspection or additionally as a facilitator to process improvement activity. The use of a high value piece of metrology equipment to purely say yes or no is often further followed with the provision of a document or report, which is required because of procedural requirements, which is safely stored until the control of records procedures allows destruction. An Original Equipment Manufacturer (OEM) may be manufacturing a low volume of chassis's which are experiencing assembly problems and might utilise a laser tracker system to identify how far out of tolerance a series of brackets is and adjust them in conjunction with the measurement engineer thus bringing the product into specification. The measurement engineer will produce a set of "inspection reports" which show final product conformance but the OEM has little knowledge of the extent of their products actual defects and thus will potentially struggle to identify the root cause of the non-conformance and ultimately repeat the process on a regular basis.

There is a fundamental importance to move the purpose of the measurement system away from judgemental inspection and perpetuate the measurement data being provided and at least use the results in a manner which aligns to the informative inspection methodology thus instigating a proactive improvement approach. The re-routing towards informative inspection has been greatly enhanced with the advances in technology and the embracement of the digital era. The advantage that has been afforded by digital data and the ability to collect rich data within the increasing array of technically advanced measurement processes can rapidly expedite informative inspection to reduce the amount of defects, in the removal of sporadic special causes or the reduction of inherent common causes. Yet, often the volume of digital data is not fully valued and is considered more of a storage burden than an improvement opportunity.

The application for an effective measurement system should be placed and considered into the realm of source inspection. The initiation of measurement away from the 
Table 1. Eight Mudas of Measurement - Lewis and Cooke 2013.

\begin{tabular}{|c|c|c|c|}
\hline $\begin{array}{l}\text { Muda of } \\
\text { manufacturing }\end{array}$ & $\begin{array}{l}\text { Measurement } \\
\text { muda }\end{array}$ & Definition & Example \\
\hline Overproduction & $\begin{array}{l}\text { Repetitive } \\
\text { measurement }\end{array}$ & $\begin{array}{l}\text { Measuring the same component or } \\
\text { feature repeatedly. This may be due } \\
\text { to a number of reasons: } \\
\text { - Measuring features at several } \\
\text { operational stages. } \\
\text { - The practice of measuring every } \\
\text { product (or feature) to ensure } \\
\text { some format of conformity or } \\
\text { customer requirement. } \\
\text { - The re-inspection of a potential } \\
\text { non- conforming product/feature } \\
\text { to confirm, or refute, the original } \\
\text { decision. }\end{array}$ & $\begin{array}{l}\text { - Measure twice and "cut once" mentality! } \\
\text { Within skilled trades such as tool-making } \\
\text { and pattern-making there is an anecdotal } \\
\text { custom to re-measure the work-piece just } \\
\text { to make sure. } \\
\text { - The manufacturing cell has measured a } \\
\text { feature as "out of specification" but the } \\
\text { inspection facility is ordered to "double } \\
\text { check" to see if the product can still } \\
\text { be sold. }\end{array}$ \\
\hline Inventory & $\begin{array}{l}\text { Measurement } \\
\text { equipment } \\
\text { inventory }\end{array}$ & $\begin{array}{l}\text { An organisation may have a wealth } \\
\text { of measurement equipment (including } \\
\text { related software) which is utilised } \\
\text { on a sporadic or occasional basis but } \\
\text { the measuring equipment has to be } \\
\text { secured, maintained and calibrated } \\
\text { within the organisations system. }\end{array}$ & $\begin{array}{l}\text { An organisation purchases a dedicated special } \\
\text { form anvil external micrometer to measure a } \\
\text { particular feature on an "alien" component. } \\
\text { After the completion of the production } \\
\text { ask the micrometer may not be required } \\
\text { again for two years but the micrometer } \\
\text { has to be controlled, to the same level, } \\
\text { as all the other measurement equipment } \\
\text { within the organisation system. }\end{array}$ \\
\hline Motion & $\begin{array}{l}\text { Movement of } \\
\text { measurement } \\
\text { staff }\end{array}$ & $\begin{array}{l}\text { Measurement staff having to move } \\
\text { between different pieces of equipment } \\
\text { or measurement systems to measure } \\
\text { various features on a component. }\end{array}$ & $\begin{array}{l}\text { A particular "inspector" may have to } \\
\text { physically relocate to a specific Co-ordinate } \\
\text { Measuring Machine because they are } \\
\text { the only person who can manipulate the } \\
\text { software in order to verify the geometry } \\
\text { requirements of a particular component. }\end{array}$ \\
\hline Waiting & $\begin{array}{l}\text { Waiting for } \\
\text { measurement } \\
\text { activity }\end{array}$ & $\begin{array}{l}\text { Products physically waiting to be } \\
\text { measured. The product cannot } \\
\text { progress to another phase until } \\
\text { it has had the particular verification } \\
\text { operation completed. }\end{array}$ & $\begin{array}{l}\text { A manufacturing process may be subjected } \\
\text { to a "first off" inspection acceptance } \\
\text { before production can continue but the } \\
\text { measurement staff or equipment are at } \\
\text { full capacity so the product has to } \\
\text { wait until there is a "time slot" available. }\end{array}$ \\
\hline Transportation & $\begin{array}{l}\text { Transportation } \\
\text { of (or to) } \\
\text { measurement } \\
\text { system }\end{array}$ & $\begin{array}{l}\text { Physically moving products to } \\
\text { another location so that a particular } \\
\text { measurement or verification process } \\
\text { can take place. }\end{array}$ & $\begin{array}{l}\text { Within safety critical industries, such } \\
\text { Aerospace or Nuclear, products have } \\
\text { to be subjected to Non-Destructive } \\
\text { Testing (NDT) processes. The NDT process } \\
\text { may be undertaken by a nominated } \\
\text { may be undertaken by a nominated } \\
\text { third party. The manufacturer would have to } \\
\text { physically transport the product to the } \\
\text { accredited laboratory and collect it after } \\
\text { completion. This process could introduce } \\
\text { other wastes such as potential for damage. }\end{array}$ \\
\hline Over-processing & $\begin{array}{l}\text { Over } \\
\text { measurement }\end{array}$ & $\begin{array}{l}\text { Inspection or measurement of a } \\
\text { component to a greater resolution } \\
\text { (decimal places) than is required. } \\
\text { N.B. Another consideration is related } \\
\text { to the output of the data gathered - } \\
\text { is it used purely to support a } \\
\text { yes/no decision or are the results } \\
\text { encompassed within a PDCA } \\
\text { improvement methodology. }\end{array}$ & $\begin{array}{l}\text { An organisation may use a variable piece } \\
\text { of measurement equipment such as a bore } \\
\text { comparator when the product could } \\
\text { be verified adequately with a } \\
\text { dedicated plug gauge. }\end{array}$ \\
\hline
\end{tabular}


Table 1. Continued.

\begin{tabular}{|c|c|c|c|}
\hline $\begin{array}{l}\text { Muda of } \\
\text { manufacturing }\end{array}$ & $\begin{array}{l}\text { Measurement } \\
\text { muda }\end{array}$ & Definition & Example \\
\hline Product defect & $\begin{array}{l}\text { Measurement } \\
\text { error }\end{array}$ & $\begin{array}{l}\text { A measurement process which is providing } \\
\text { the wrong classification of data. (A non- } \\
\text { conforming product is declared satisfactory } \\
\text { or conversely a satisfactory feature } \\
\text { is condemned as non-conforming } \\
\text { product.) }\end{array}$ & $\begin{array}{l}\text { A measurement system may have a } \\
\text { systematic error. During a shift pattern } \\
\text { an external micrometer, used within } \\
\text { a production cell, may have been dropped } \\
\text { and subsequently damaged. The external } \\
\text { micrometer could be used by an alternate } \\
\text { shift and assumed to be correct } \\
\text { and product verified incorrectly with it. }\end{array}$ \\
\hline $\begin{array}{l}\text { Unused } \\
\text { employee } \\
\text { creativity }\end{array}$ & $\begin{array}{l}\text { Under } \\
\text { utilisation of } \\
\text { measurement } \\
\text { staff }\end{array}$ & $\begin{array}{l}\text { Highly skilled measurement staff who } \\
\text { are measuring component to a } \\
\text { yes/no decision. }\end{array}$ & $\begin{array}{l}\text { A production cell may have poorly } \\
\text { trained production staff or a flawed } \\
\text { measurement system which has produced } \\
\text { a quantity of non-conforming product. } \\
\text { A highly skilled member of the inspection } \\
\text { team has been assigned to "plug gauging" } \\
\text { the defective product when they could } \\
\text { have been assigned to provide training } \\
\text { for the production team or review and } \\
\text { improve the measurement system. }\end{array}$ \\
\hline
\end{tabular}

product verification mind set and placed upstream into measuring and controlling the process parameters. The identification of the critical constraints and the development of an astute measurement system to reduce the variation within the process performance will have the effect of primarily eliminating defects.

There can often be an acute (operational) assumption that a product may be measured for verification processes only because it's a "one off" but strategically the organisation could do lots of "one offs" and thus the culmination of data could be analysed to identify long term trends for process improvement.

The analytical software Minitab, which functionally heavily supports the Six Sigma DMAIC improvement methodology, has a dedicated Gage R\&R Study (Crossed) capability. Within the supporting Minitab user guide the choice is presented to the user of which calculated resultants can be utilised:

- If the measuring system is used for process improvement (reducing part-to-part variation), \%StudyVar is a better estimate of measurement precision.

- If the measurement system evaluates parts relative to specifications, \%Tolerance is a more appropriate metric.

The presentation of the decision of which metric to use presents a subliminal message that measurement data is optional. The organisation undertaking the gauge $R \& R$ study are potentially being told that it is acceptable to create a measurement system that is for verification purposes only and that because they have used results within the \%Tolerance column they never have to consider improving the performance of the measurement system or consider the minimisation of the inherent common causes within the product under investigation. This does suggest something of a contradiction between Minitab's provision and the fundamental breakthrough strategy which is at the heart of the DMAIC improvement methodology.

\section{Conclusion}

Any measurement system is a process and as such it can be analysed within the constraints of the lean philosophy and all measurement systems can in theory be divided into value added and non-value added activity. The identification of these endeavours can be perpetrated by lean tools such as value stream mapping to analyse and attain a ratio between value adding and non-value adding activity.

The urgency for controlled metrology within industry and the scientific arena is extremely important [32,33] and to support this demand the metrology manufacturing OEM's have enhanced technology to introduce rapid advancements within the field of measurement equipment. An organisation could place a substantial investment and supporting resource within an advanced piece of measurement equipment which dramatically reduces the duration of the value added activity but bears no consideration upon the surrounding non value adding activity. The investment within technical equipment could actually create further non-value adding activity. The provision of an immense quantity of data will arguably fuel Ohno's [18] concern "excess information must be suppressed" as this indulgence in more data is supporting the waste of over processing. Therefore organisations need to avoid this scenario and use data for continual improvement.

It is proposed that non-value adding activity can be synthesised using the "eight wastes of metrology" and 
reported using simple tools such as Pareto analysis to present key wastes within the process (measurement system). Potentially an organisation may be able to remove the effects identified as measurement wastes with simplistic procedural changes and staff training.

One of the fundamental conclusions regarding the creation of a lean measurement system is that the non-value adding wastes are potentially attributed to assorted bad practice. The lean message of non-value added waste has subconsciously attached itself into inspection functions and measurement activity and as such has become the target for streamlining and funding removal as a holistic function rather than the target of process improvement activity. These measurement process wastes have been inherent and understood for numerous years and there are many existing methodology for prevention of the "eight wastes of manufacturing". There is an opportunity to apply this knowledge to metrology and measurement systems and with the relevant training, staff and resources the creation of a lean measurement system is very achievable.

Acknowledgements. The authors would like to thank Professor Alistair Forbes of the National Physical Laboratory for his interest and continued support with this line of research. The authors would also like to thank Dr Ray Jones Coventry University for his feedback and support.

\section{References}

1. J.S. Oakland, TQM: Text with cases, 3rd edn. (Butterworth-Heinemann, Elsevier Ltd., Oxford, 2003)

2. J.S. Oakland, Statistical Process Control, 5th edn. (Butterworth-Heinemann, Elsevier Ltd., Oxford, 2003)

3. N. Slack, S. Chambers, C. Harland, A. Harrison, R. Johnston, Operations Management, 2nd edn. (Pitman Publishing, London, 1998)

4. J.E. Ross, Total Quality Management: Text, Cases and Readings, 3rd edn. (St Lucie Press, New York, 2000)

5. J. Bicheno, The Lean Toolbox, 2nd edn. (Picsie Books, Buckingham, 2000)

6. R.J. Schonberger, Japanese Manufacturing Techniques: Nine hidden lessons in simplicity (Collier Macmillan Canada Inc., 1982)

7. K. Murata, A. Harrison, How to make Japanese Management methods work in the west, 1st edn. (Gower Publishing, Aldershot, 1993)

8. J.P. Womack, D.T. Jones, Lean Thinking: Banish waste and create wealth in your corporation, 2 nd edn. (Simon \& Schuster UK Ltd, 1998)

9. T. Boyle, M. Scherrer-Rathje, I. Stuart, Learning to be lean: the influence of external information sources in lean improvement, J. Manuf. Tech. Manag. 22, 587-603 (2011)

10. K. Durward, I.I. Sobek, A. Smalley, Understanding A3 Thinking. A critical component of Toyota's PDCA management system, 1st edn. (Productivity Press, Boca Raton, 2008)

11. A. Furlan, A. Vinelli, G. Dal Pont, Complementarity and lean manufacturing bundles: an empirical analysis, Int. J. Oper. Prod. Manag. 31, 835-850 (2011)
12. J. Angelis, R. Conti, C. Cooper, C. Gill, Building a highcommitment lean culture, J. Manuf. Tech. Manag. 22, 569-586 (2011)

13. P. Hines, N. Rich, M. Hittmeyer, Competing against ignorance: advantage through knowledge, Int. J. Phys. Distrib. Logistics Manag. 28, 18-43 (1998)

14. Womack et al., The machine that changed the world: How lean production revolutionized the global car wars, 2nd edn. (Simon \& Schuster, 2007)

15. A.P. Smart, R.S. Maull, S.J. Radnor, T.J. Housel, An approach for identifying value in business processes, J. Knowledge Manag. 7, 49-61 (2003)

16. L.K. Sim, W.J. Rogers, Implementing lean production systems: barriers to change, Manag. Res. News 32, 37-49 (2009)

17. M. Braunscheidel, J. Hamister, N. Suresh, H. Star, An institutional theory perspective on Six Sigma adoption, Int. J. Oper. Prod. Manag. 31, 423-451 (2011)

18. T. Ohno, Toyota Production System: Beyond Largescale Production, English translation (Maple-Vail Book Manufacturing Group, 1988)

19. J.K. Like, The Toyota Way: 14 Management Principles from the world's greatest manufacturer (McGraw-Hill Education, 2004)

20. P. Hines, N. Rich, The seven value stream mapping tools, Int. J. Oper. Prod. Manag. 17, 46-64 (1997)

21. A.M. Sanchez, M.P. Perez, Lean indicators and manufacturing strategies, Int. J. Oper. Prod. Manag. 21, 14331451 (2001)

22. P. Hines, N. Rich, A. Esain, Value stream mapping: A distribution industry application, Benchmarking: An Int. J. 6, 60-77 (1999)

23. Z. Radnor, D. Barnes, Historical analysis of performance measurement and management in operations management, Int. J. Prod. Performance Manag. 56, 384-396 (2007)

24. C. Jimmerson, A3 Problem Solving for Healthcare (Healthcare Performance Press, New York, 2007)

25. Z. Radnor, Muddled, massaging, manoeuvring or manipulated? Int. J. Prod. Performance Manag. 57, 316-328 (2008)

26. E. Palmer, D. Parker, Understanding performance measurement systems using physical science uncertainty principles, Int. J. Oper. Prod. Manag. 21, 81-999 (2001)

27. E.W. Deming, Out of the Crisis (The MIT Press, London, 1982)

28. M. Walton, The Deming Management Method: The Complete Guide to Management, 2nd edn. (Dodd, Mead \& Company Inc., 1992)

29. S. Shingo, Zero Quality Control: Source Inspection and the Poke-yoke System (Productivity, Inc., Cambridge, 1986)

30. D.K. Macbeth, Advanced Manufacturing. Strategy 8 Management (IFS Ltd., Bedford, 1989)

31. K. Stout, Quality Control in Automation (Kogan Page Ltd, London, 1985)

32. J.N. Pan, Determination of the optimal allocation of parameters for gauge repeatability and reproducibility study, Int. J. Qual. Reliab. Manag. 21, 672-682 (2004)

33. S. Rabinovich, Measurement Errors: Theory and Practice (AIP Press, Woodbury, NY, 1995) 